Nina Maria ROSCAN

Faculty of Letters, University of Bucharest

Bucharest, Romania

ninaroscan@yahoo.com

\title{
TRAUMA AND MEMORY IN MAYA ANGELOU'S AUTOBIOGRAPHICAL FICTION
}

Recommended Citation: Roscan, Nina Maria. "Trauma and Memory in Maya Angelou's Autobiographical Fiction.” Metacritic Journal for Comparative Studies and Theory 5.1 (2019): https://doi.org/10.24193/mjcst.2019.7.08

Abstract: The purpose of this paper is to explore Maya Angelou's depiction of trauma in her autobiographical fiction as a marginalized female experience which shapes the identity of the subject and speaks about the psychological integrity of the Black female. Memory functions as the process of psychological healing through the narrative reformulation of her life during childhood and adulthood. Angelou has deliberately expanded the conventional structure of the autobiographical genre by the fragmentary approach and the rejection of the idea of alterity based on cultural differences, which she has rather attributed to the existing power relations, and by making use of self-censorship techniques such as silences, metaphors, signifiers in order to fight injustice. My paper is based on the series of seven autobiographical novels by Maya Angelou, published between 1969 and 2013.

Keywords: autobiography, women, race, trauma, memory, self-censorship techniques.

In autobiographies, we encounter a self and their doings, reflections, thoughts and place in the world. Whereas the subject is deceptively simple, the referent is a difficult matter to specify and the various theories that explain it need a thorough understanding.

Life writing practices are connected with the concept of agency, they show how meanings are created for people. Agency is precisely the ability of individuals to negotiate societal systems to make meanings that allow them to act in the world. 
Recently, a new interest in autobiography is expanding the genre, even academics mix their critical reviews with memoirs and elements of life writing. Maya Angelou herself acknowledged the performativity of words when recounting the terrible experience of testifying in court against her abuser who was later killed for his crime and left Maya with the guilt that her words can lead to negative consequences. In the second novel, she revisits the importance of words when joining the Southern Christian Conference after hearing a speech by Martin Luther King Jr. on the civil rights movement and realized that words have the power to change the world.

The beginning of writing the self in African American literature is constituted by the slave narrative which is a genre that mixes history, politics, autobiography and literature. Because of the subjectivity of self-representation, a very reasonable question is whether the slave narrative is fiction or history or what is the boundary between truth and fact.

Although Romanticism was the cultural trend that emphasized the individual and the little cosmos inside every individual that needs to be discovered, it was not until Enlightenment that the rational "I" was placed at the center of the universe and lead to the rise of politicians like Henry Adams, philosophers like John Stuart Mill or authors like Charles Dickens who included autobiographical elements in their works. Contemporary memoirs on the other hand, have the purpose to speak of pain and trauma and to make the less oppressed aware of the oppressed while at the same time they are experiences of becoming for the author, hence the interconnectedness between literature and history. Slave narratives were themselves powerful literary works and persuasive tools to convince the truth assumed in them.

The autobiographical novel offers multiple opportunities to explore personality, even if the autobiographer narrates negative experiences in his life, these are evidences for the true human nature which is prone to both failure and success. However, the majority of autobiographies have social, aesthetic and ethical dimensions as they present examples of "good lives". The Postmodern autobiography is more problematic from this point of view, the ethical dimension is challenged, the author does not follow a chronological display of events but inserts episodes from other past moments to show the complexity of human consciousness.

Maya Angelou's autobiography is not an easy reading for the reader who seeks to escape immediate reality and immerse herself in an idyllic universe. Instead, it 
offers an honest incursion into the American culture and history with all its practices, beliefs and contradictions. Her narrative invites for active participation, expects to trigger a reaction in the behavior of the reader that discovers events in the life of African Americans at the middle of the $20^{\text {th }}$ century in the South of the United States.

In order to fit the experience of black women, Maya Angelou expanded the autobiographical genre and thus enriched the concepts of literature and history by making visible a marginalized group - women autobiographers - who destroyed the myth of the women's role in society, the myth of motherhood and maternity, the myth of the luxurious life in the South of the United States, the "true womanhood cult," the bourgeois Eurocentric perspective, and called for searching one's own identity and individuality. First-person accounts have been considered unsuitable and too daring for women for a long time; however, African-American women have wisely used literature as a tool to raise their voice and speak about social, political and cultural issues that they have experienced.

In the nineteenth century, the autobiographies reached to the audiences and their message had been heard by numerous white women who were involved in the abolitionist movement. Given the popularity of the sentimental novel in the era, the readers had certain expectations regarding the genre. However, Harriet Jacobs' Incidents in the Life of a Slave Girl (1861) challenges her readers' assumptions and portrays the real relationship between women at that time, which made white women revise their behavior towards their black sisters. By subverting the sentimental novel, autobiographers exposed the hypocrisy of the myth of a "true woman" created by a patriarchal society which locked women in the domestic areas and denied them access to the public platform from which to make their voices heard:

Women are considered of no value, unless they continually increase their owner's stock. They are put on a par with animals. This same master shot a woman through the head, who had run away and been brought back to him. No one called him to account for it. If a slave resisted being whipped, the bloodhounds were unpacked, and set upon him, to tear his flesh from his bones. The master who did these things was highly educated, and styled a perfect gentleman. He also boasted the name and standing of a Christian, though Satan never had a truer follower (Jacobs 55). 
Nineteenth century male slave narratives were guided by abolitionists and followed the model of European tradition of writing autobiographical accounts with an emphasis on the individual and represented a reflection of a Puritan society; whereas women's autobiographical accounts focused more on family and community. Frederick Douglass, Olaudah Equiano or Booker T. Washington's accounts were self-centered narratives about strong, independent men in search for freedom. On the other hand, women autobiographers emphasized topics that are usually not the focus of men such as the destruction of family ties under the slavery system and their works were open-ended, inviting the reader to complete the missing parts. As a comparison, some of Olaudah Equiano's chapters are named as if pertaining to an adventure book, as follows: The author is carried to Virginia-Arrives in EnglandHis wonder at a fall of snow (chapter III); The author's disgust at the West IndiesForms schemes to obtain his freedom (chapter VII); The author arrives at Martinico -Meets with new difficulties, and sails for England (chapter IX). Whereas, in Harriet Jacobs' Incidents, the majority of her chapters refer to topics related to the domestic sphere and family life: The Trials of Girlhood (chapter V); The Jealous Mistress (chapter VI); The Children Sold (chapter XIX); Aunt Nancy (chapter XXVIII); The Meeting of Mother and Daughter (chapter XXXII); A Home Found (chapter XXXIV).

Moreover, it was mandatory for African American women to authenticate their accounts through statements written by trustworthy white personalities. The need to prove the authenticity of an autobiographical account is rooted in men's need to control the public arena by censoring literary works that were unsuitable for a woman's status. The public sphere was not destined to women and not in the least degree to black women. After the Preface, which contains an apology to the reader for the audacity of pursuing a bold undertaking, there is an Introduction by the Editor, Lydia Maria Child who testifies for Jacobs' work and reinforces the message of authenticity:

The author of the following autobiography is personally known to me, and her conversation and manners inspire me with confidence. During the last seventeen years, she has lived the greater part of the time with a distinguished family in New York, and has so deported herself as to be highly esteemed by them. This fact is sufficient, without further credentials of her character. (...) It will naturally excite surprise that a woman reared in Slavery should be able to write so well. But 
circumstances will explain this. In the first place, nature endowed her with quick perceptions. Secondly, the mistress, with whom she lived till she was twelve years old, was a kind, considerate friend, who taught her to read and spell. (...) I am well aware that many will accuse me of indecorum for presenting these pages to the public; for the experiences of this intelligent and much-injured woman belong to a class which some call delicate subjects, and others indelicate (Jacobs 5).

Another method for retracting the tools necessary to write was denying the right to literacy. Women's life writing becomes both confrontational and conciliatory in their effort to get the attention of powerful people who were impressed by their accounts and could plead for equal rights. Literacy meant power; it allowed African Americans not only to make their voices heard and fight against oppression but to preserve cultural memory and past cultural traditions. Henry Louis Gates even argues that literacy helped demonstrate the membership to the human community (Gates 12).

Another purpose of life writing concerned the destruction of myths and stereotypes such as the "true womanhood cult" originally created by men's desire to control the status of women who were supposed to be submissive and pure, but which practically proved to be "cages" that denied freedom of expression and access to fundamental rights. Harriet Jacobs, in particular, approaches in her work the conflicted relationship between the so-called "hysterical" white mistress and the "promiscuous" black servant who seduced the white master, when in fact the roots of the conflict is the evil nature of slavery which denied black women numerous rights and the patriarchal Puritan type of American society which denied white women freedom of expression and to act on the political arena. Even if black women became victims of both white women's rage and white men's oppression, they were able to acknowledge the importance of community and "sisterhood" which meant the creation of bonds between women of any color and shape and address instances of cultural and personal trauma.

While the white family imposed for women the domestic, private and non-political role, in which the man was the provider of the family and part of the public sphere, in the black family the situation has always been different. Black women's roles as mothers and child nurturers were inseparable from work. While bringing up their children at home, they had to attend work on the fields as well. This gave them income and made them producers as well as provided women 146 
with more authority within the family, which was perceived as equality between the sexes more than in the white families.

Working and raising children concurrently had several drawbacks; mothers had to rely on other females in the community to care for the children, a practice which changed the relations between females in the community and their perception of motherhood. The nuclear family was a fantasy; Maya Angelou herself recounts several experiences in the 1960 s when it was necessary to rely on other mothers from the community to attend to her son, Guy, while working around Europe and the United States. In her sixth novel, A Song Flung Up to Heaven, she laments the lack of institutions of child-care that African Americans needed for their children while they continued to work. Angelou expressed her dissatisfaction towards the political actions in Watts; she could not settle with the authorities' promise of a child-care institution and requested a complete change in the situation of African Americans. The practice of "othermothering" was particularly frequent among working mothers, Angelou recounts several maternal figures in the neighborhood who represented the "mothers on duty" for many children whose parents were working to support the family:

Mrs. Violetta Robinson, often called the Mother of Watts, told them what the women of Watts needed- an accredited, well-funded child-care center so that they could leave their children and go to work with clear minds. Something of slavery lurked in the shadow of that request (Angelou 1100).

Maya Angelou gives an account of the profound effects which trauma had upon her identity and the continuous struggle for the reconstruction of the fragmented self, in the series of seven autobiographical novels which started to be published in 1970. Memory plays an essential role in the reconstruction of the self. The process of narrative reformulation which enables Maya Angelou to rediscover her identity implies the recollection of the traumatic impact, all throughout her childhood, adolescence and adulthood.

Angelou's autobiographic fiction acquires a character of "scriptotherapy" (McQuail) through which she updates the triumph that gives sense to her apparently senseless existence as an abuse victim, but also represents a form of resistance against oppression. Cathy Caruth in her interdisciplinary study, Unclaimed 
Experience: Trauma, Narrative and History (1955), describes the literary and performative dimensions of Freud, Lacan and Derrida's texts. Starting from its Greek etymology which at first had meant a body wound, the concept of trauma was extended to the field of psychology and its meaning has become broader than a simple pathology; it is the story of the distress of a wounded psychic, a recurrence through memory of the traumatic impact which repeats itself in the consciousness of the subject. What comes to haunt the victim is not the violent image of the trauma, but the incomprehensibility of it, the inability to understand the reality of the event (Caruth 115).

Marguerite Johnson, the protagonist of Maya Angelou's autobiographical fiction often remembers the abuse caused by her mother's partner, Mr. Freeman, at the age of eight, accompanied by feelings of guilt for participating in a forbidden act and also disappointment with an adult. The emotional anesthesia provoked by this event is the expression of what Suzette Henke calls existential crisis, the shatter of the victim's identity which emerges in relation to alterity (Henke 107-121).

In her article, Reembodying the Self: Representations of Rape in Incidents in the Life of a Slave Girl and I Know Why the Caged Bird Sings (1992), Mary Vermillion explores the consciousness of the rape victim and introduces the term somatophobia (Vermillion) as a condition defined by the fragmentation of identity as the result of a traumatic event. Vermillion compares Harriet Jacobs' Incidents in the Life of a Slave Girl with Angelou's first autobiographical novel arguing that while Jacobs posits somatophobia outside of herself and criticizes it as part of the slaveholding culture, Angelou presents it as internalizing and challenging racist conceptions of the black female body. As a child, Angelou rejects her identity by nurturing feelings of contempt towards her black curly hair and tall body and imagines herself as "one of the sweet white girls who were everybody's dream of what was right with the world" (Angelou). Later she realizes the wrecking force of her psychological insecurity and the lack of self-awareness as described in her fourth autobiographical novel The Heart of a Woman (1981) when she travels to Ghana and rediscovers the beauty of her ancestry.

Memory is the process by which trauma is recalled. Pierre Nora (1989) discusses the difference between the two meanings of the term, on the one hand the lived history as a representation, on the other, the psychological process by which we 
can make history intelligible. From these perspectives, Maya Angelou's autobiographic novels are relevant for the manner in which History can be reconstructed through the personal stories of the marginalized. The formation of the African-American identity can also be explored from the perspective of the theory of cultural trauma. As a cultural process, trauma is mediated through a series of representations which distort the collective memory. After the abolition of slavery, in the period after the Civil War, the idea of a unique African-American identity emerged.

Although forced servitude and the complete dependency on the landlord were not directly experienced by many authors, including Maya Angelou, they are essential for the construction of an identity from the remembrance of these events. Hence, slavery becomes traumatizing in retrospect as it lies at the basis of the collective memory.

Angelou denounces trauma as a cultural process in multiple episodes including the episode in which the most important person in her life, grandmother Henderson, was humiliated by a group of white children who called her by her first name. Little Maya was the helpless witness to this endurance test and tried to understand her grandmother's choice to remain silent. Silence is a recurrent form of resistance against oppression in Angelou's works, after the traumatic abuse Marguerite refuses to talk for two years, she understands the performative power of words which can lead to her abuser's condemnation:

He was gone, and a man was dead because I lied. (...) I discovered that to achieve perfect personal silence all I had to do was to attach myself leechlike to sound. I began to listen to everything. I probably hoped that after I had heard all the sounds, really heard them and packed them down, deep in my ears, the world would be quiet around me (Angelou 87).

Another relevant scene for the issue of social and cultural trauma, and also for the capacity of the collective memory to restructure identity is the episode of the secondary school graduation, when the speech by a member of the school board offends the African American members of the audience who start to sing James Weldon Johnson's Lift Ev'ry voice. This activates the collective memory of African Americans' suffering caused by the delayed effects of slavery meliorated by African 
American songs and tales, as Angelou narrates in the first novel (1969) about black people's gratitude towards poets and preachers whose voices supported their fight for survival:

O Black known and unknown poets, how often have your auctioned pains sustained us? Who will compute the lonely nights made less lonely by your songs, or the empty pots made less tragic by your tales? (Angelou 1997)

The power of spoken and written words is another key concept specific to African American life writing beginning with Richard Wright's Black Boy (1945). A man was condemned as a consequence of her speaking, which enables Marguerite to understand the role of the words that she can use later in life for artistic and political purposes. Afterwards, literature has helped the child to understand that imagination can feed words with a power that can be used for high aspirations (Eyerman). This episode of self-censorship turns Maya into a highly introverted child who spends her days reading Shakespeare and Dostoyevsky and other great writers who shaped her language and enabled her to prepare for later roles of journalist, poet and autobiographer unintimidated to speak about issues that were previously less explored, such as childhood trauma.

Angelou discovered in her early childhood the power of words. Later in life, autobiography became a feminist tool for expression that sent political and artistic messages of social change. After her first novel, The Caged Bird, which had an episodic structure and focused on individual experiences, the structure of her writing shifted into fragments and reflections about the general black woman's experience in the world. This shift from the individual consciousness and a teleological perspective of the first novel, to her later novels which lacked a central experience and an episodic nature, is the abandonment of the first person singular "I" in favor of first person plural "we", it is the transition from the experience of a black girl in the South of the United States to the story of every black woman in America. Suddenly, the canvas that Maya Angelou created became so ample that it included miscellaneous groups of people with diverse experiences in various geographical regions in the world, and even if each had its own specificity they influenced and shaped each other. Not one single person or item in the canvas was isolated or without significance to the whole narrative. 
The traumatic experience of rape in her childhood produced a period of many years of silence in which she refused to speak but she decided to sharpen her hearing, sight and memory by reading and memorizing numerous works of literature from the local library, which later provided her with a renewed world perspective. Angelou read substantial works by Shakespeare, Edgar Allan Poe, Dostoyevsky, Paul Lawrence Dunbar and Countee Cullen, and acknowledged that she continued a tradition started by Frederick Douglass and Harriet Jacobs, which is the slave narrative. Reading the older writers provided her with a classic vocabulary that is partially Victorian and biblical, although her novels kept a simple, conversational and often emotional tone.

She gathered the words to create the work which would later become one of the most important, but also censored, books in American literature. According to The Office for Intellectual Freedom of the American Library Association, Caged Bird was banned for many years from schools because it was considered to advocate hatred towards white persons and contained explicit language that described a sexual aggression. She even stands the eighth position in a top most-challenged-authors since 1990 to 2004, according to a study made by the American Library Association, being surpassed by J. K Rowling or Stephen King. However, Angelou did not intend to use euphemisms in her autobiographies to describe terrible situations that she had experienced, nor was her intention to shock readers, her purpose was to get a reaction from the readers, to make them aware of a black girl's experience in America in the 1930 s and become a participant in the fight for human rights and equality.

Scholars generally agree that there is a special woman's way of approaching language and communication without suggesting that there is an inherent biological essentialism, but rather this uniqueness results from the fact that the author is a woman, a product of a certain culture whose selection of words, silences and selfcensorship techniques are used with veiled meanings. Stover (2003) argues that this new feminist language is a "mother tongue" that shapes and adjusts their stories of survival from the mental and physical oppression of slavery and its effects.

The majority of the mother tongue techniques used by nineteenth century women writers have their origin in the slavery system which made African Americans masters of the use of secrecy, double meanings, mumbling, signifying, selfcensorship, thus they developed ways to communicate that were different to the 
master's as tools for survival. Silence was also a technique of their discourse that is particularly frequent in literature.

Henry Louis Gates in his study, The Signifying Monkey, extensively analyzes the aspect of signifying that characterizes the African American folklore and pleads for the existence of a distinctive idiom of nineteenth century writers and also a different type of autobiography, not as a subgenre but as a counter-genre which purposefully constructed double-voiced discourses. Women succeeded to be part of the change process through this dialect which encompasses the entire history of the African Americans in which women use mixtures of diverse elements. In order to decipher the whole meaning of women's writing, the reader must possess a broader vision on literature.

African-American female writers' autobiographies have always represented vehicles for messages of support between each other, resistance against oppression and therapy against abuses, they constitute documents with historical value, these little histories which fix the great History usually told only by dominant groups, especially white European males, come to destroy myths and stereotypes about women deposited throughout time. Angelou's fiction in particular enriches the concepts of literature and history by making visible a marginalized group - women autobiographers - who destroyed the myth of women's role in society, the myth of motherhood and maternity, the myth of the luxurious life in the South of the United States, the "true womanhood cult" (Koyana), the bourgeois Eurocentric perspective, and called for searching for one's own identity and individuality. African-American women have wisely used literature as a tool to raise their voice and speak about social, political and cultural challenges that they have experienced.

Post-colonialism and postmodernism are deconstructed by the experience of Black women; their autobiographies speak about the identities created during times of neocolonialism and global capitalism in which powerful states impose their cultural practices and try to dominate economically the less developed states. This dominance has resulted in migrancy and homelessness, because "home" was the space characterized by specific gendered relations, usually a male-dominated space where Black women experienced physical or psychological trauma and which proved to be "cages" for outspoken women. Black women's autobiographies deconstructed "home" as the idealized and romanticized image due to their displacement and the 
sense of not belonging (Smit 1). Home has contradictory meanings: the country of origin or the imperial country; Maya Angelou often associates home in her autobiography to Africa, the place of her ancestors' origin and the ideal space where the problem of the color line disappears, she acknowledges in her sixth novel that:

There was an obvious justification for my amorous feelings. Our people had always longed for home. For centuries we had sung about a place not built by hands, where the streets were paved with gold, and were washed with honey and milk. There the saints would march around wearing robes and jeweled crowns. There we would study war no more and, more important, no one would wage war against us.

The Southern roads and cages are symbols of a troubled history in which slavery was grounded and supported by racism and the negation of basic rights. Maya Angelou rendered a different representation of the African American female, rejecting norms of true womanhood, she has created a unique work which acquires historical and sociological significance for the present day woman as a survivor. Being a black woman in the South during the 1930's represented a dual prejudice, as women suffered from the white hegemony and the male discrimination. Angelou's novels expanded the autobiographical genre by exploring themes such as the importance of family and nurturing one's children, the quest for self-sufficiency, personal dignity and self-definition, the rejection of an idealized female beauty that creates feelings of inadequacy and self-hatred, trauma, displacement, social rejection and political activism. James Baldwin called Angelou's first autobiography "a beginning of a new era in the minds and hearts of all black men and women" (Cox 7).

Angelou has been surrounded by profoundly religious people who participated every Sunday in the Baptist or Methodist Church service, however she rendered the connection with the church in a different manner than the previous authors. Angelou narrates with humor the obsolete practices of African American religious tradition, while at the same time keeping a special affection towards the religious roots of her community, by contrast Zora Neale Hurston, for example, reports through her folklorist lens the cultural aspects of this tradition, without objecting with regards to the practices that may entertain the younger generation.

The series of seven autobiographical novels does not only recreate the world of a little black girl in the 1930's American South as narrated so many times before, in 
slave narratives and other novels, but it also offers historical continuity which is of utmost importance for readers nowadays.

Maya Angelou's contribution to the autobiographical genre is one of the most consistent in the American literature. Her quest for individuality and the refined use of humor distinguish her work from the previous ones. The most considerable success of her effort is to demystify the previously accepted conception of a nuclear patriarchal family, based on the institution of marriage and the meaning of motherhood which was different for middle class women, immigrants and other minorities. There was at the time a fixed definition for what people could understand as a family or a wife. Debunking the enchanted perspective that privileged groups used to have about family life, Angelou undertook the difficult task of emphasizing the dynamic between family, home (or the domestic sphere) and the larger economic context.

According to the Cambridge History of African-American Literature, amongst other African American authors from the mid-twentieth century onward, two of the earliest in the "social conscience" group were Rosa Guy and John Killens. Together, they founded a creative writing workshop attended by Maya Angelou, Audre Lorde and Paule Marshall. The 1970's were the most significant years in the production of contemporary African American works, there was a high demand for and reception of black literature which redefined the meaning, functions and aesthetic of art by reinvesting in orality and storytelling.

Although all Angelou's autobiographical novels contain important themes that challenge the reader, Caged Bird caught the attention of literary critics the most for its profound moral stance and resistance to racism, sexism and poverty through language, imagery, truth-telling perspective and meaning of the text. Joanne Braxton had the opportunity to meet Angelou for an interview in which Angelou admitted the difficulty of her decision to start writing autobiography as literature, since autobiography was taught in history classes in academic settings. Among the many perspectives to writing a critical analysis of Angelou's work, Joanne Braxton chose to explore the way Maya Angelou's autobiographical fiction embodies memory. Braxton collected seven essays about Caged Bird and two interviews with Angelou between 1975 and 1995, representing two decades of scholarship devoted to Angelou's autobiographical fiction. 
As an intellectual herself, Maya Angelou acknowledges the "special" position that the black intellectual possessed within the academia, tracing a short history of American black intelligentsia is especially challenging and rewarding, as it reveals how the black intellectual enriches and completes the missing parts of history, with his insights on the power relations and how the existing power relations can shape and distort a group while benefiting the other.

In an interview from 1977 Angelou stated that the amount of experiences and roles is part of her life narrative as if pertaining to a painting process: "everything is part of a large canvas I am creating, I am living beneath" (Challener 50). Maya Angelou's autobiography is particularly relevant because it invites an understanding of the history of the African American community in the United States of America but it also invites an active participation, and aims to obtain a reaction against injustice and inequality caused by racial, gender and class discrimination.

\section{References:}

Angelou, Maya. "I Know Why the Caged Bird Sings." The Collected Autobiographies of Maya Angelou. The Modern Library, 2004.

Caruth, Cathy. Trauma Explorations in Memory. John Hopkins University Press, 1995.

Cox, Vicki. Black Americans of Achievement, Maya Angelou, Poet. Chelsea House Publishers, 2006.

Challener, Daniel. Stories of Resilience in Childhood. Garland Publishing, 1997.

Eyerman, Ron. Cultural Trauma. Slavery and the Formation of African American Identity. Cambridge University Press, 2003.

Gates, Henry Louis. The Slave's Narrative. Ed. by Charles T. Davis, Oxford University Press, 1990.

---. The Signifying Monkey. A Theory of African-American Literary Criticism. Oxford University Press, 1989.

Henke, Suzette. “Maya Angelou's Caged Bird as Trauma Narrative.” Bloom's Modern Critical Views- Maya Angelou, edited by Harold Bloom. Infobase Publishing, 2009.

Jacobs, Harriet. Incidents in the Life of a Slave Girl. Penguin Classics, 2000. 
Walker, Pierre. "Racial Protest, Identity, Words, and Form in Maya Angelou's I Know Why the Caged Bird Sings.” Harold Bloom's Modern Critical ViewsMaya Angelou, edited by Harold Bloom. Infobase Publishing, 2009.

McQuail, Josephine A. "Scriptotherapy in Toni Morrison's The Bluest Eye and Maya Angelou's I Know Why the Caged Bird Sings.” IRWLE, vol. 5, no. 1, January 2009.

Vermillion, Mary. "Reembodying the Self: Representations of Rape in Incidents in the Life of a Slave Girl and I Know Why the Caged Bird Sings." University of Hawai'I Press, Vol. 15, No.3, summer 1992: 243-260

Nora, Pierre. "Between Memory and History: Les Lieux de Memoire." University of California Press, Representations, no. 26, spring 1989: 7-24.

Koyana, Siphokazi. "The Heart of the Matter: Motherhood and Marriage in the Autobiographies of Maya Angelou.” Paradigm Publishers, The Black Scholar, Vol. 32, No. 2, "Black America After 9/11," summer 2002.

Smit, Johannes, "Black Women, Writing and Identity," review article of Black Women, Writing and Identity. Migration of the Subject by Carole Boyce. Davies, Routledge, 2004. 